\title{
Adaptive simulation of the impact of changes in land use on water resources in the lower Aswa basin
}

\author{
Martine Nyeko, ${ }^{1}$ Guido D'Urso, ${ }^{2}$ Walter W. Immerzeel ${ }^{3}$ \\ ${ }^{1}$ Department of Biosystems Engineering, Faculty of Agriculture and Environment, Gulu University, \\ Gulu, Uganda; ${ }^{2}$ Department of Agricultural Engineering and Agronomy, University of Naples \\ Federico II, Portici (NA), Italy; ${ }^{3}$ Department of Physical Geography, Faculty of Geoscience, Utrecht \\ University, Utrecht, The Netherlands
}

\begin{abstract}
In the lower Aswa basin, Uganda, the changes in land use due to complex demographic and social economic factors are among the numerous challenges facing management of the limited water resources. The current study analysed the degree to which water yield in the Aswa basin could be changed by altering the vegetation cover (here considered to be agricultural use and forest) at the basin and sub-basin level, and whether manipulation of vegetation cover can complement water resource management objectives in the study area. The distributed hydrological process Soil Water Assessment Tool (SWAT) model was used to simulate the impact of the changes in vegetation cover on water balance. The impact was compared with the water balance simulated using the year 2001 as baseline. The results showed that: $37.5 \%$ afforestation at the basin scale can reduce water yield by $15.85 \%$; using $53.7 \%$ of the land for agriculture can increase water yield by $27.6 \%$, while a combination of $23.2 \%$ forest and $52 \%$ agriculture can increase water yield by $24.85 \%$. The location of forest and agricultural land cover with respect to rainfall regime also indicated a notable impact on sub-basin water balance. In particular, afforestation in sub-basins receiving less than $900 \mathrm{~mm}$ annual rainfall considered as $d r y$ showed minimum change in surface runoff and net water yield, while in sub-basins receiving more than $900 \mathrm{~mm}$ annual rainfall afforestation showed notable change in water yield. In this way, afforestation in $d r y$ sub-basins can be used to offset the afforestation pressure in the wet sub-basin without altering the basin water balance.
\end{abstract}

Correspondence: Martine Nyeko, Department of Biosystems Engineering, Faculty of Agriculture and Environment, Gulu University, Gulu, Uganda.

Tel. +256.712033303 .

E-mail: m.nyeko@gu.ac.ug

Key words: change in land use, water balance modelling.

Received for publication: 22 August 2012.

Accepted for publication: 14 December 2012.

(C) Copyright M. Nyeko et al., 2012

Licensee PAGEPress, Italy

Journal of Agricultural Engineering 2012; XLIII:e24

doi:10.4081/jae.2012.e24

This article is distributed under the terms of the Creative Commons Attribution Noncommercial License (by-nc 3.0) which permits any noncommercial use, distribution, and reproduction in any medium, provided the original author(s) and source are credited.

\section{Introduction}

Land use and the hydrologic systems are known to be systematically linked. More precisely, land use controls processes of interception, and evapotranspiration which subsequently affects storage and flows. In the long term, it is believed that changes in evapotranspiration due to changes in land cover affect rainfall distribution on a regional or continental level (Savenije, 1995). The impact of changes in land use on hydrology can be studied using either a catchment experiment (Bosch and Hewlett, 1982) or hydrologic processes models (Li et al., 2007). In the latter approach, land use is manipulated while the hydrologic processes are observed during simulations. The hydrologic process models have been extensively used in recent simulation of the impact of changes in land use on hydrology and it is considered to present a big advantage over catchment experiments given its more flexible, rigorous and enabling mechanistic interpretation (Beven 1996, 1993). In addition, the results of the impact are immediately available for the resource planner or manager.

Integrating land use planning and water resource management is quite vital in the contemporary management of water and land resources. For example, it has been suggested that afforestation may reduce water yield (Li et al., 2007; Bosch and Hewlett, 1982). However, due to the complexity of hydrologic processes, which in many cases are affected by local factors such as weather, soil and land use, generalising the impact of changes in land use to inform decision-making on planning land use and water resource management is often discouraging (Kiersch and Tognetti, 2002). This limitation creates an incentive towards adaptive site-specific simulation of the impact of changes in land use on water resources for their effective management. In the Aswa basin, there is an urgent need to integrate land use planning in water resource management since man's livelihood is directly dependent on land use and water supplies are dwindling.

The current study explores the degree to which water yield in the lower Aswa basin can be changed by altering vegetation cover, referred to in this study as agriculture and forest, and whether this manipulation of vegetation cover can complement water management objectives in the study area. The key assumptions used in this study are that knowledge of the relationships between changes in land use and hydrologic processes present a great opportunity to adapt the management of land and water resources in the area.

\section{Materials and methods}

\section{The study area}

The study was conducted in the lower part of the Aswa basin (Figure 
1) located in northern Uganda. The area covers approximately 12,225 $\mathrm{km}^{2}$, almost half the area of the entire basin $\left(27,601 \mathrm{~km}^{2}\right)$, with over 1 million inhabitants deriving their livelihood directly from the land. Land cover is mainly comprised of woodlands and savannah grassland. The natural forest (mainly deciduous trees) covers very little of the catchment area (>0.5\%). The savannah grassland covers most of the study area and is dominated by short grasses (3-4 metres) and shrubs. There is a wide diversity of woodland in the study area. There is a unique blend of semi-arid woodland in the north-eastern part, dominated mainly by short grasses and openly grown acacia, and savannah woodland consisting of open trees with short grasses (Figure 1).

\section{Soil data}

The Soil and Terrain Database for north-eastern Africa, at a scale of 1:1,000,000 according to the United Nations Food and Agriculture Organisation, was used to obtain the soil units and soil properties. Soil properties included: soil hydrologic group, maximum rooting depth of soil profile, soil texture (including percentage of rock for each soil layer), soil layer depth, moist bulk density, available water capacity of the soil layer, saturated hydraulic conductivity, organic carbon content, moist soil albedo and soil erodibility factor.

\section{Climatic data}

Three weather stations (Figure 2) with fairly consistent records were considered. The climatic records for the years 1999, 2000 and 2001 were used in the simulation (both baseline and reference). The year 1999 and 2000 were used as warm-up periods during simulations while the year 2001 provided the simulation period used in deriving the water balance information. By fixing the climate parameters or using the same records in simulation of baseline and reference water balance, the effects of climate on the water balance, which can be confused with impact of land use change, are eliminated.

\section{Delineation of the study area}

The basin was delineated into sub-basins and similar climatic zones. Sub-basin delineation was performed using the Soil Water Assessment Tool (SWAT) watershed delineation tool. Digital elevation model-based stream definition was used to derive flow direction and accumulation. A minimum drainage area of $16,000 \mathrm{ha}\left(160 \mathrm{~km}^{2}\right)$ was used to obtain the stream network. Approximately $12,000 \mathrm{~km}^{2}$ of watershed area, with a total of 40 sub-basins, was delineated (Figure 2).

An annual rainfall distribution map was used to delineate the three major climatic zones, here defined as dry, wet and very wet (Figure 2). The climatic zones were used in assessing if there is any effect on water resource availability by allocating the three land use scenarios in either of the climate zones.

\section{Land use data}

The land use data for this study were adopted from Nyeko (2010). The land use dataset consists of a baseline land use map, obtained for the year 2001 using image classification of landsat images and the land use scenarios obtained using an integrated geographical information system (GIS) and multi-criteria decision process. The scenarios were derived only for changes in agricultural land use and forest land use considered important land use issues.

The baseline land use map was classified with an overall accuracy of $81.48 \%$ and coefficient of 0.782 using supervised image classification techniques (Nyeko, 2010). Biophysical parameters known to influence land use change, e.g. soil fertility, altitude, population density, rainfall distribution, land use, accessibility and availability of water, were developed and used in simulation of land use scenarios. A multi-criteria decision process using the analytical hierarchy process according to
Saaty, (1980) was used to assign weights to the parameters. The weighted linear combination approach according to Jiang and Eastman (2000) implemented in ArcGIS (Esri, Redlands, CA, USA) was used to develop a suitability map (Nyeko, 2010). The criteria used to allocate

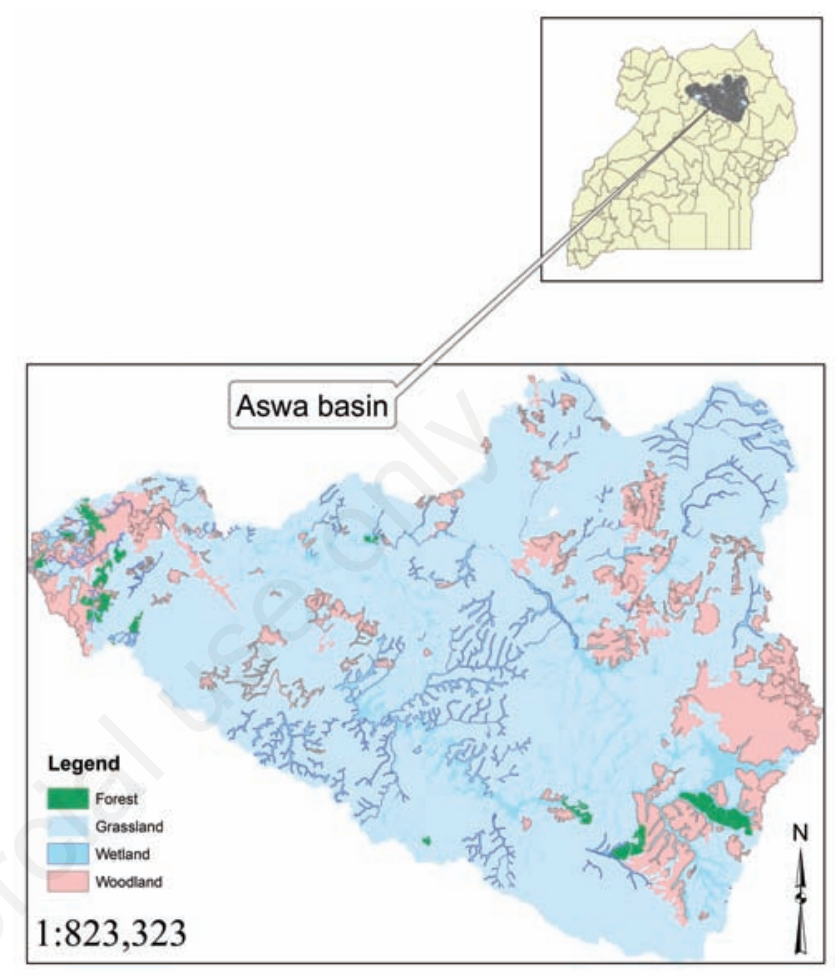

Figure 1. The major land cover types in the study area (adapted from Africover: http://www.africover.org/).

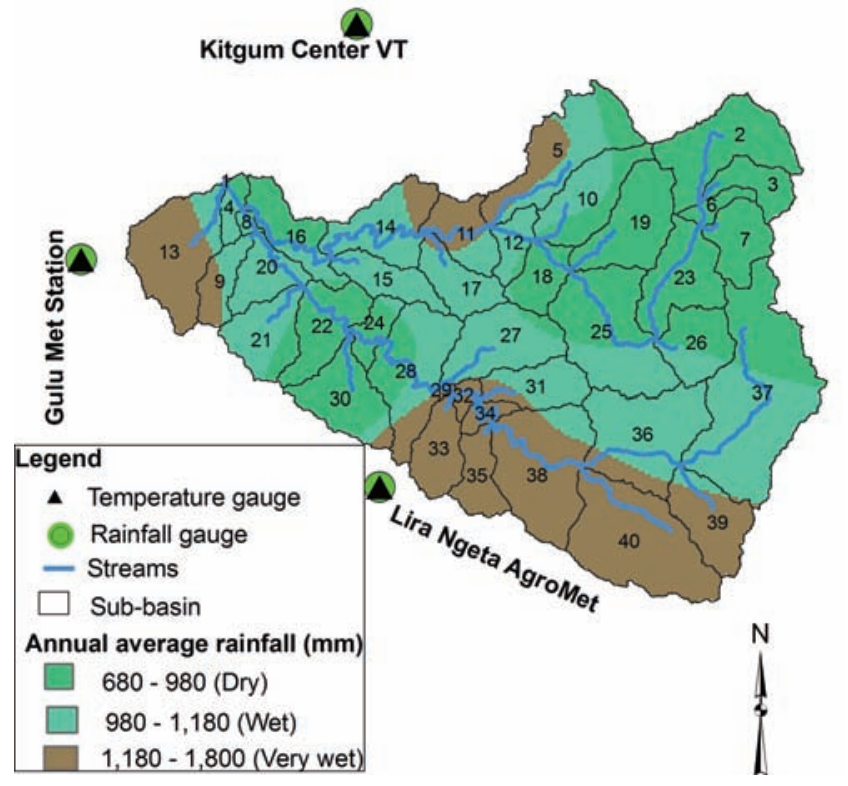

Figure 2. The sub-basin delineation showing main climatic zones. 
land parcels to forest took into consideration environmental protection, including priority allocation of land parcels with low vegetation cover to forest and constraining allocation of wetlands to forest. On the other hand, access to water source and land fertility was used in allocation of land to agriculture. To complement environmental protection, wetland and forest cover were restricted from allocation to agriculture. The final land use scenarios did not consider when in the future the land use pattern could develop. However, the scenarios provided an opportunity for testing policies of spatial change in land use (agriculture and forest). Three land use scenarios (forest, agriculture and agroforestry development) were considered (Figure 3).

Details of the spatial pattern of the afforestation scenario are shown in Figures 4-6. The scenario tests the impact of moderate to extensive spatial afforestation policies on water resource management. The allocation varies from $4 \%$ (sub-basin 6) to over $80 \%$ (sub-basins 34 and 13). Meanwhile, the spatial pattern of the scenario of changes in agricultural land use (Figure 5) shows the extent of possible changes in agriculture land use varying from less than $2 \%$ to more than $90 \%$. The scenario tests the impact of moderate to extensive spatial agricultural policies on water resource management.

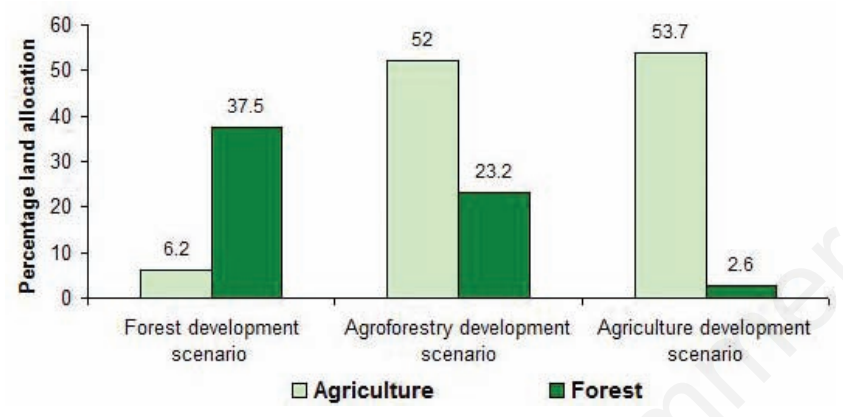

Figure 3. The configuration of the three scenarios at basin level.

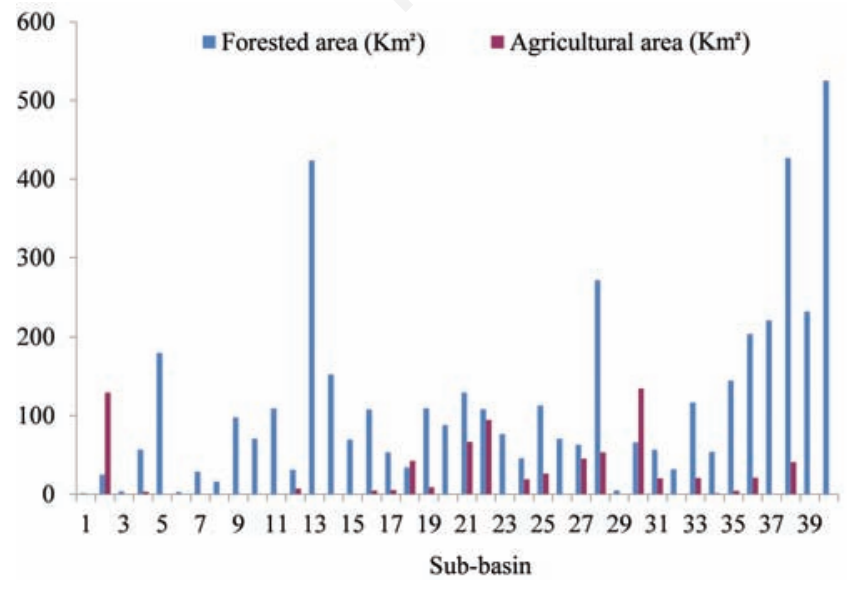

Figure 4. Spatial graphical representation of the afforestation scenario.
Agroforestry scenario (Figure 6) shows mixture of forest and agriculture in the sub-basins. The scenario is meant to test the impact of the spatial agro-forest policies on water resources management.

\section{Soil Water Assessment Tool model}

The distributed hydrologic process model SWAT was used in this study to simulate the hydrologic impact of change in land use. The model was chosen for its capability in simulating the land phase of the hydrologic processes (Arnold and Fohrer, 2005), the relatively low data input requirement, and the ability to generate missing weather records during simulation or fill in gaps in weather records.

The SWAT model according to Arnold et al. (1998) is a conceptual and physically-based model developed to predict the effect of land management practices on water, sediment and agricultural chemical yield in a large complex watershed with varying soil, land use and management conditions over long periods of time. The model has an explicit spatial parameter space and is coupled to GIS to simplify the pre- and post-processing of spatially distributed data. The model component includes: weather, hydrology, soil temperature, plant growth, nutrients and pesticides. The SWAT model has been extensively used in hydrolog-

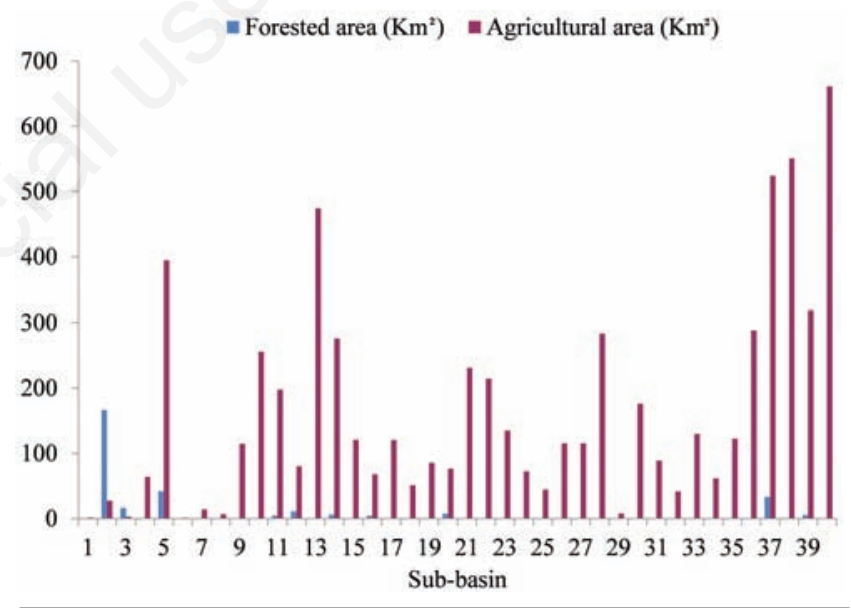

Figure 5. Spatial graphical representation of the agriculture land use change scenario.

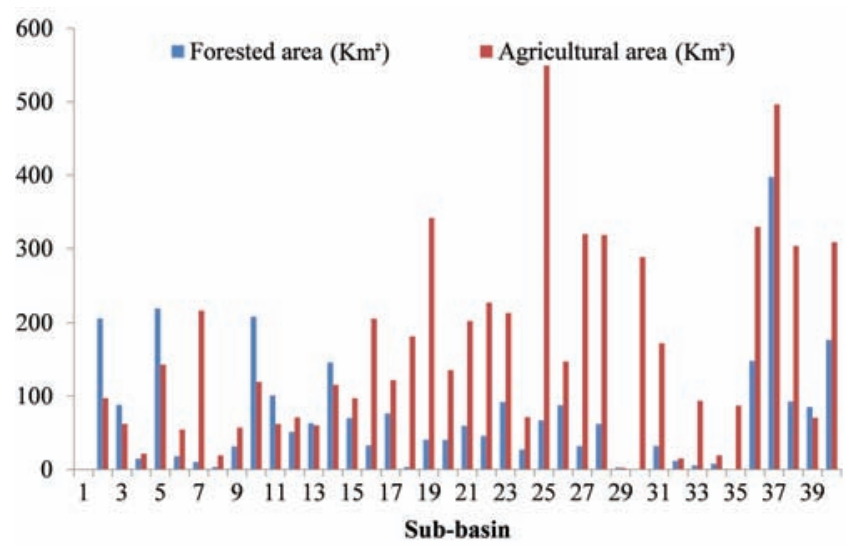

Figure 6. Spatial graphical representation of the agroforestry scenario. 
ic modelling at different spatial scales and scopes (Gollamudi et al., 2007; Zhang et al., 2007; Chu and Shirmohammadi, 2004; Santhi et al., 2001; Spruill et al., 2000). Hydrologic processes simulated by SWAT are based on the water balance equation:

$$
S W_{t}=S W_{o}+\sum_{i}^{t}\left(R_{\text {day }}-Q_{\text {surf }}-E_{a}-W_{\text {seep }}-Q_{g w}\right)
$$

where

$S W_{t}$ is the final soil water content $\left(\mathrm{mm} \mathrm{H}_{2} \mathrm{O}\right)$;

$S W_{o}$ is the initial soil water content on day $i\left(\mathrm{~mm} \mathrm{H}_{2} \mathrm{O}\right)$;

$t$ is the time (days);

$R_{d a y}$ is the amount of precipitation on day $i\left(\mathrm{~mm} \mathrm{H}_{2} \mathrm{O}\right)$;

$Q_{\text {surf }}$ is the amount of surface runoff on day $i\left(\mathrm{~mm} \mathrm{H}_{2} \mathrm{O}\right)$;

$E_{a}$ is the amount of evapotranspiration on day $i\left(\mathrm{~mm} \mathrm{H}_{2} \mathrm{O}\right)$;

$w_{\text {seep }}$ is the amount of water entering the vadose zone/exiting the bottom of the soil profile (root zone) on day $i\left(\mathrm{~mm} \mathrm{H}_{2} \mathrm{O}\right)$; and

$Q_{g w}$ is the amount of lateral flow on day $i\left(\mathrm{~mm} \mathrm{H}_{2} \mathrm{O}\right)$.

The SWAT model set up, calibration and validation were performed in a previous study by Nyeko (2010). Calibration and validation used historical monthly streamflow records. The performance of the model in predicting the streamflow during the calibration was evaluated using both statistical and graphical methods. In particular, the graphical techniques used provided visual comparison of the simulated and measured hydrograph. The coefficient of determination $\left(\mathrm{R}^{2}\right)$ from the graphical evaluation was obtained as 0.618 . Nash-Sutcliffe efficiency (NSE), according to Nash and Sutcliffe (1970), was use to provide the statistical evaluation of the calibrated model. The NSE value of 0.47 , which is the measure of how well the plot of the observed data versus the simulated data fits the 1:1 line, was obtained.

\section{Results and discussion}

Surface runoff was used as the hydrologic indicator in discussing the impact of land use scenarios at sub-basins. Surface runoff generation is considered to be more sensitive to land use change because of its quick response to changes in land cover. At basin level, the impact of land use scenarios on baseflow, shallow aquifer recharge and deep aquifer recharge were considered.

\section{The impact of afforestation scenario}

Basin scale impact of afforestation scenario on hydrology (Figure 7) shows a reduction in net water yield of $25.98 \mathrm{~mm}$ (equivalent to $15.85 \%$ of the baseline), a reduction in surface runoff of $6.42 \mathrm{~mm}$ (equivalent to $35.69 \%$ of the baseline), a reduction in baseflow of $19.62 \mathrm{~mm}$ (14.89\% of the baseline) and an increase in actual evapotranspiration (ET) by $28.30 \mathrm{~mm}$ (2.35\% of the baseline scenario). Sub-basin impact of afforestation scenarios on hydrology at a sub-basin level (Figure 8) shows a reduction in simulated surface runoff in most sub-basins. However, in a few sub-basins, mostly in $d r y$ areas, the impact of afforestation indicates a slight increase (19.5\%) in simulated surface runoff. According to Bosch and Hewlett (1982), afforestation normally caused a reduction in surface runoff due to an increase in interception losses and evapotranspiration losses. Croke et al. (2004), however, noted that the hydrologic system is subject to a different kind of spatial complexity, and is dynamic and random in nature. According to Brooks et al. (2003), water yield response to changes in land cover is more significant in areas with deep soils and high annual precipitation and less significant in areas with less precipitation and shallow soil. The response in sub-basin 2 and other sub-basins, which shows an increase in surface runoff despite an increase in forest cover, cannot, however, be easily explained and may not be due to spatial complexity, but may rather be due to model uncertainty. In the SWAT model, plant growth may be reduced due to temperature stress, water stress and nutrient stress. Both stresses affect the development of biomass and conse-

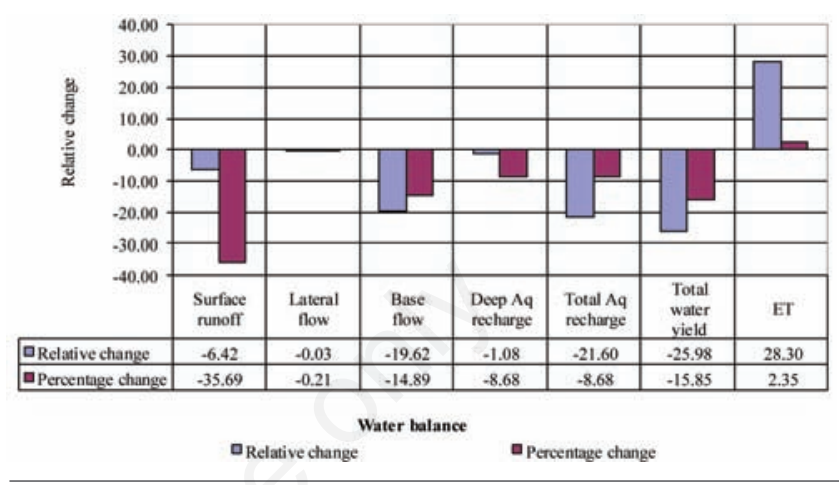

Figure 7. Impact of afforestation scenario on basin water balance.

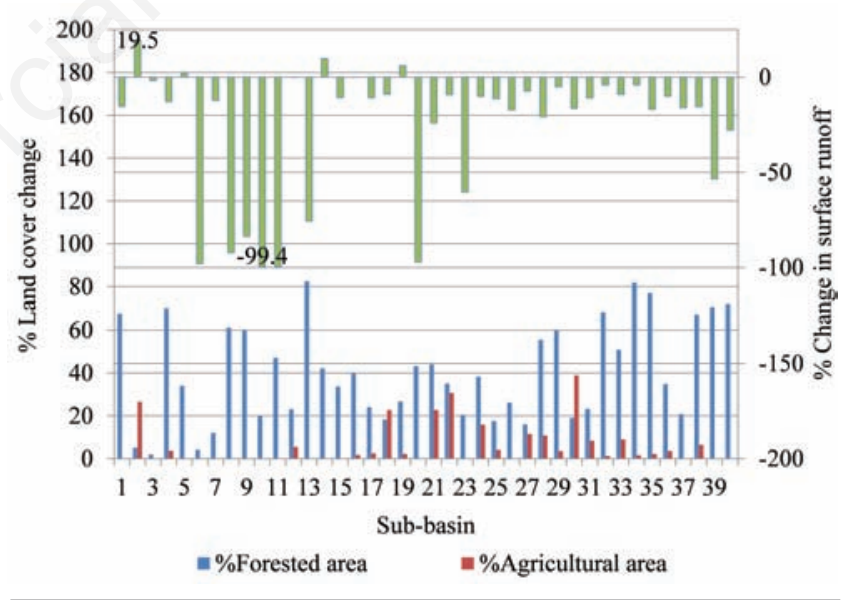

Figure 8. The impact of afforestation on surface runoff at subbasin level.

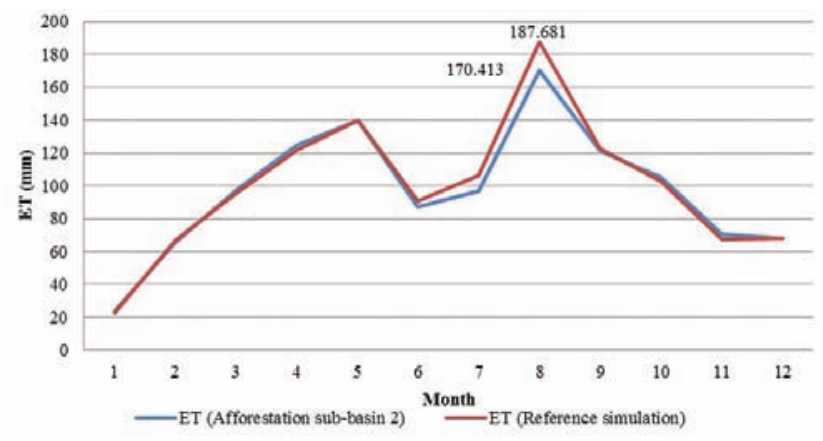

Figure 9. Change in evapotranspiration (ET) at sub-basin 2. 
quently the ET. It can be seen that evapotranspiration at sub-basin 2 in the month of August drops significantly (-17.268 mm) (Figure 9), and this could have resulted in an increase in surface runoff.

\section{Agro-forestry development scenarios}

At basin level, the agroforestry scenario caused an increase in surface runoff of up to $61.48 \%$ of the baseline, an increase in baseflow of $22.44 \%$ and an increase in net water yield of $24.85 \%$ (Figure 10 ).

At a sub-basin level, the agroforestry scenario shows a highly variable impact on simulated surface runoff (Figure 11). Thirteen subbasins mainly located in the dry area show a net decrease in simulated surface runoff, while twenty sub-basins located mainly in wet and very wet areas show a net increase in simulated surface runoff.

The impact on the $d r y$, wet and very wet sub-basins was also highly variable. In sub-basin 26 , for example, surface runoff is increased by $225 \%$ corresponding to a $32.58 \%$ increase in forest and $54.69 \%$ increase in agriculture. In sub-basin 29 , however, surface runoff was reduced by approximately $5 \%$ corresponding to a $22.5 \%$ increase in agriculture and a $26.2 \%$ increase in forest. The difference in the response in the subbasins can be attributed in part to the rainfall regime i.e. climatic variation. It is also seems that variation in simulated surface runoff is

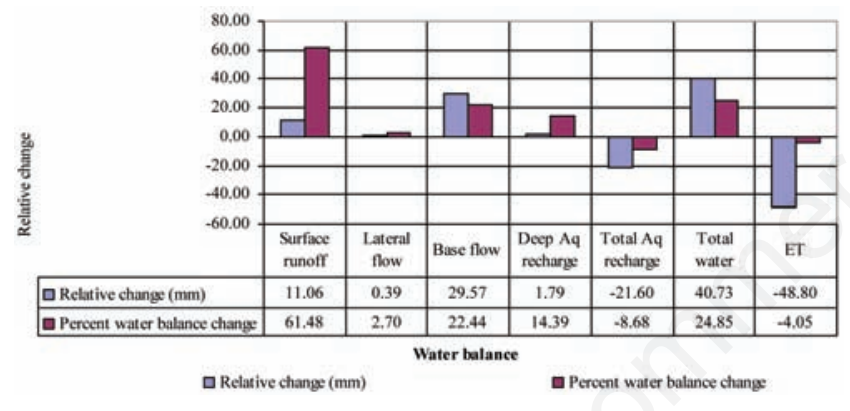

Figure 10. Impact of agroforestry scenario on water balance at basin level.

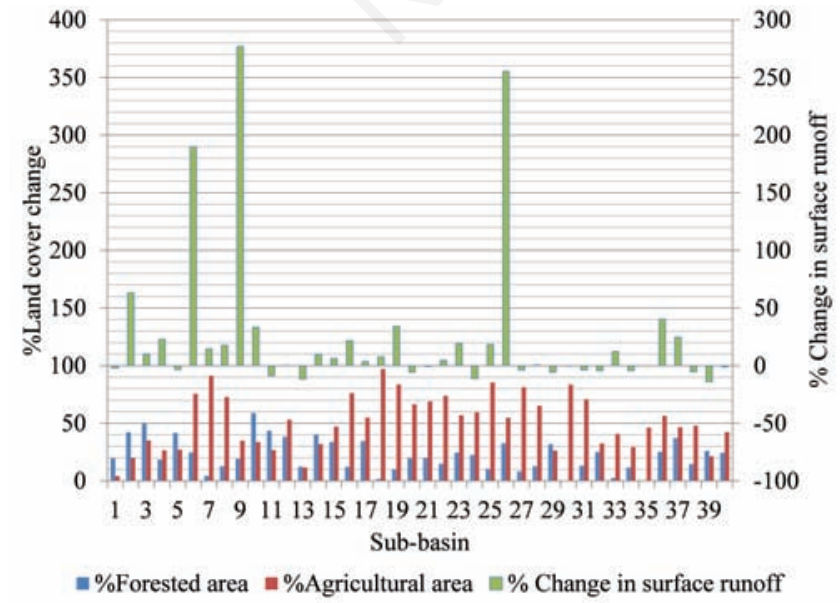

Figure 11. The impact of agroforestry scenario on surface runoff at sub-basin level. affected by the order in which the land cover in the baseline scenario is changed, for example, forest or agriculture replacing rangeland, which are perhaps more or less demanding on water resources, respectively. The results shown in sub-basins 26 and 29 indicate that the impact of afforestation on surface runoff is less significant when proportionate allocation is also made to agriculture in a given sub-basin.

\section{Agriculture development scenario}

At basin level, increasing the area of land used for agriculture caused a notable increase in surface runoff (70.09\%), baseflow (24.95\%), total aquifer recharge (27.60\%) and total water yield (27.60\%) (Figure 12).

At A sub-basin level, the impact of increasing mainly agriculture land cover on simulated surface runoff is minimum $( \pm 20 \%)$ (Figure 13). In few sub-basins, however, changes in agricultural land use caused a notable increase in simulated surface runoff; for example, in subbasins $1,4,9,13$ and 16 runoff was increased by $63 \%, 69 \%, 177 \%, 34 \%$ and $134 \%$, respectively (Figure 13).

The highly variable impact of agriculture on simulated surface runoff presents another complexity and uncertainty of the hydrology processes. The significant variation in simulated surface runoff can be in part attributed to rainfall regime as earlier on noted.

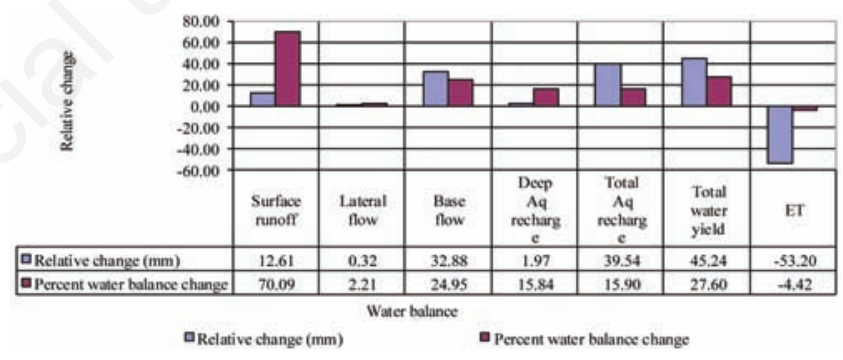

Figure 12. Impact of agriculture scenario on water balance at basin level.

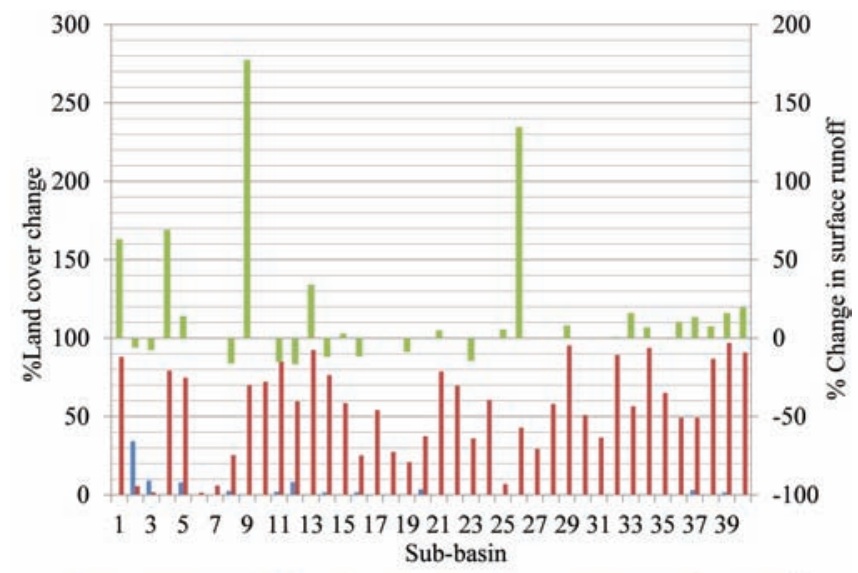

$\approx \%$ Forested area $=\%$ Agricultural area $\approx \%$ Change in surface runoff

Figure 13. The impact of agriculture land use change scenario on surface runoff at sub-basin level. 


\section{Conclusions}

In the current study, we investigated the impact of changes in spatial afforestation, agroforestry and agricultural land use policies on water resource availability. It was noted that the three land use scenarios have a unique impact on water resource availability, with afforestation reducing water yield, while agroforestry and agricultural land use both increasing water yield at a basin level. At sub-basin level, it was noted that a proportionate increase in afforestation and agriculture results in a insignificant change in water yield, for example, a 5\% increase in water yield corresponding to a $22.5 \%$ increase in agriculture and a $26.2 \%$ increase in forest cover. In addition, afforestation in $d r y$ areas had less impact on water yield while in the wet and very wet sub-basins afforestation had a considerable impact on water yield. Afforestation in the $d r y$ zones can, therefore, be used to offset afforestation pressure in the wet areas without significantly affecting water yield.

\section{References}

Arnold J.G., Fohrer N. 2005. Current capabilities and research opportunities in applied watershed modeling. Hydrol. Proc. 19:563-72.

Arnold J.G., Srinivasan R., Muttiah R.S., Williams J.R. 1998. Large area hydrologic modeling and assessment. Part I. Model development. J. Am. Water Res. Assoc. 34:73-89.

Beven K. 1993. Prophecy, reality, and uncertainty in distributed hydrological modeling. Adv. Water Res. 16:41-51.

Beven K.J. 1996. Equifinality and uncertainty in geomorphological modeling. In: Rhoads B.L., Thorn C.E., eds. The Scientific Nature of Geomorphology. Wiley, Chichester, UK, pp 289-313.

Bosch J.M., J.D. Hewlett. 1982. A review of catchments experiments to determine the effect of vegetation changes on water yield and evapotranspiration. J. Hydrol. 55:3-23.

Brooks K.N., Folliott P.F., Gregesen H.M., Debano L.F. 2003. Hydrology and the management of watershed. Blackwell Publishing, Ames, IA, USA.
Chu T.W., Shirmohammadi A. 2004. Evaluation of the SWAT model's hydrology component in the Piedmont physiographic region of Maryland. Trans. ASAE 47:1057-73.

Croke B.F.W., Merritt W.S., Jakeman A.J. 2004. A dynamic model for predicting hydrologic response to land covers changes in gauged and ungauged catchments. J. Hydrol. 291:115-31.

Gollamudi A., Madramootoo C.A., Enright P. 2007. Water quality modeling of two agricultural fields in southern Quebec using SWAT. Trans. ASABE 50:1973-80.

Jiang H., Eastman J.R. 2000. Application of fuzzy measures in multi-criteria evaluation in GIS. Int. J. Geogr. Informat. Syst. 14:173-84.

Kiersch B, Tognetti S. 2002. Land-water linkages in rural watersheds: Land use and water resources research. In: FAO. Land-water linkages in rural watersheds electronic workshop, 18 Sept-27 0ct, 2000. Land and Water Bulletin No. 9. Rome, Italy.

Li K.Y., Coe M.T., Ramankutty N., De Jong R. 2007. Modeling the hydrological impact of land-use change in West Africa. J. Hydrol. 337:25868.

Nash J.E., Sutcliffe J.V. 1970. River flow forecasting through conceptual models, Part I - A discussion of principles. J. Hydrol. 10:282-90.

Nyeko M., 2010. Land use changes in Aswa Basin Northern Uganda; Opportunity and constrains to water resources management. Degree Diss., University of Naples Federico II, Naples, Italy.

Saaty T.L. 1980. The analytical hierarchy process. McGraw-Hill, New York, NY, USA.

Santhi C., Arnold J.G., J.R. Williams, Hauck L.M., W.A. Dugas. 2001. Application of a watershed model to evaluate management effects on point and nonpoint source pollution. Trans. ASAE 44:1559-70.

Savenije H.H.G. 1995. New definitions for moisture recycling and the relation with land-use changes in the Sahel. H. Hydrol. 167:57-78.

Spruill C.A., Workman S.R., Taraba J.L. 2000. Simulation of daily and monthly stream discharge from small watersheds using the SWAT model. Trans. ASAE 43:1431-9.

Zhang X., Srinivasan R., Hao F. 2007. Predicting hydrologic response to climate change in the Luohe River basin using the SWAT model. Trans. ASABE 50:901-10. 